\title{
Reduction of entrepreneurial risk as the purpose of legislative initiatives: research results
}

\section{Introduction}

This article presents the results of a research project which has been the first undertaking of this kind in the history of institutional economics and legal theory at the same time. The project provided for carrying out comprehensive and long term research on the entire legislative process in a country (Poland) over more than twenty years.

The project was financed by the Polish National Science Centre pursuant to decision-DEC-2013/09/B/HS5/04078. The title of the project was 'Application of Statistical Methods to Determine the Nature of Long-term Trends Occurring in the Legislative Process'.

\section{Research methodology}

The research results proved the main initial hypothesis, whereby it was assumed that the establishment of formalized institutions of the economy followed long-term trends which had resulted from the forces of supply and demand, similar to the provision of any other goods, whether tangible or intangible.

At the outset of the project, detailed research problems were defined following the theoretical assumption on the presence of the main categories of economic and social factors which determined the matters 
addressed in legal regulations. Research into these problems led to the assessment whether or not, to what extent, and how frequently the same factors affected the course of the legislative process. The assessment of the impact of these factors was carried out taking into consideration their importance in the adoption of a legislative act. The research method was based on expert reviews: each legislative act was reviewed by three experts (a lawyer, an economist, and a sociologist) who independently provided their evaluation by way of answering the research question. Subsequently, an average value was calculated separately for each of the acts, based on all the expert evaluations. The data obtained in this way were aggregated into numerical sequences corresponding to periods of time (time sequences), where the time unit was one year, and then, the variations in numerical values were laid out in the graphic form as diagrams.

The assumption was made to study the effect of the factors which determined $g$ legislative proposals in relation to only one of the sources of law, namely, the legislation passed in Poland in the years 1990-2013 (twenty-four years). The justification underlying this assumption was substantial, as the laws of a lower rank in Poland, by and large, only implement regulations, and their provisions merely elaborate on provisions contained in respective legislative acts, thus (simply) following the directions set out by the legislature. Therefore, the laws of a lower rank cannot produce a major change in the trend related to the social and economic requisites of the legislative process. The analysis covered a vast majority of legislative acts passed by the Sejm of the Republic of Poland (the Polish parliament) in the years 1990-2013 (3,087 legislative acts ). The only acts to be excluded from the analysis were those of a technically legal nature. Another very important aspect was the fact that a prevailing majority of these acts (at least 95\%) concerned a specific area of socio-economic relations (i.e., a law was meant to achieve a specific socio-economic purpose, to resolve a specific matter, which could be easily seen from the formal justification assessments accompanying the legislative acts).

In the evaluation process each legislative act was assessed from the point of view of detailed research questions evaluated on a seven-grade scale. The idea was to highlight the obvious differences in the socio-economic importance of some of these regulations.

For each of the research questions, in relation to each of the 3,087 legislative acts, one of the following values was to be determined: 


\section{$-3-2-10123$}

The values were assigned depending on the level of convergence between the effect of the regulation and the assumption underlying a given research question: from " 3 " (a strong, substantial positive correlation with the effect assumed in the research question), to "-3" (a strong, substantial negative correlation with the effect assumed in the research question), where the " 0 " value implied the absence of the effect assumed in the research question.

Mathematical methods were applied in order to transform the values assigned by experts to each of the research questions, into time sequences. The sequences obtained in this way were quantifiable variables (figures), for which levels could be calculated from year to year. These variables were used, among others, to graphically illustrate (as diagrams) the changing trends in the values assigned for successive years ${ }^{1}$.

Two main mathematical modelling approaches were used: the values and the changes occurring in them were aggregated, which was referred to as the aggregate figures approach, and average values and changes in the average values were calculated, which was referred to as the average figures approach. Without going into the details of the two mathematical approaches, it is enough to note for the purposes of this publication that the aggregate figures approach can basically be applied to establish the actual values assessed for particular years and for specific detailed research questions, which roughly reflected the emphasis placed in the legislative process, while the average figures approach was more oriented towards measuring the socio-economic importance of the regulations adopted in a given year. In other words, the quantitative approach also alluded to the qualitative aspect of the process (whether or not the focus placed by law makers on a particular issue was translated, on the one hand, into the number of the adopted laws, and on the other, into their significance from the point of view of shaping the socio-economic relations in a particular year). An auxiliary method was also used to determine successive time sequences which were referred to as discrete sequences. The purpose of establishing these discrete sequences was to identify the sequences of solely positive or clearly positive values (or, alternately, solely negative or clearly

${ }^{1}$ For a more elaborate discussion of the statistical methods used for the purposes of the project see M. Sobczyk Statystyka, PWN, Warszawa 1991, and M. Magiera, Modele i metody statystyki matematycznej, Wrocław 2002. 
negative values) in a given year, while, at the same time, disregarding all other values, i.e., zero and negative values, or (accordingly) zero and positive values ${ }^{2}$.

It is important to note the quantitative distribution of the total number of legislative initiatives in particular years, which were included within the scope of this research. The figures reflecting the numbers of legislative acts in specific years are presented in the diagram below.

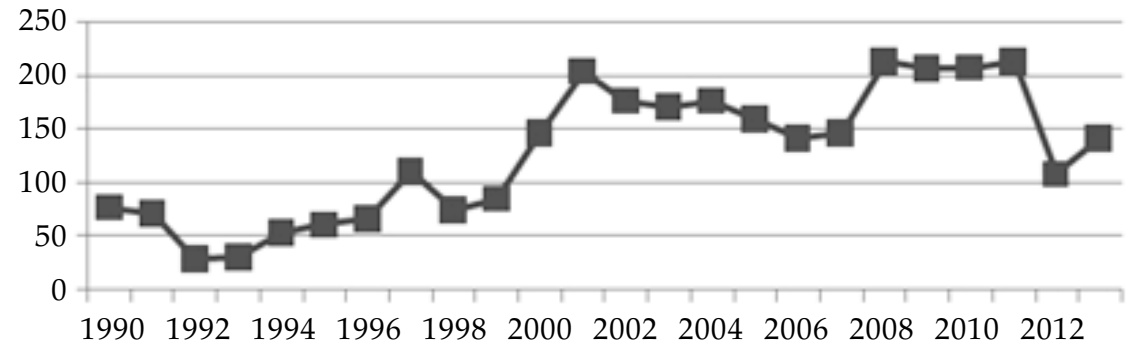

Fig. 1: The number of analysed legislative initiatives for particular years.

Source: P. Chmielnicki.

The analysis of the diagram presenting the number of legislative acts for the respective years, that were included in the research, is important to the extent that it allows determining whether or not the diagram which illustrates the scope of this particular research project by and large reflected the overall numbers of adopted legislative acts. If this is the case, indeed, it would imply that, roughly speaking, law makers continued to focus in their work on specific matters, on which regulations were adopted, or in other words, that certain issues enjoyed a steady interest from the legislature, which was proportional to the overall volume of legislative work. A similar approach may be applied in order to interpret any diagram presenting average figures for a more or less stable trend, with no major growth or decline. A more rapid growth (or decline) in the values attributed to a particular area, as compared to the growth (or decline) in the total number of legislative acts adopted in a particular year, would indicate, respectively, either a reinforcement or weakening

${ }^{2}$ For a more detailed discussion of the mathematical modelling approach see M. Stachura, in: P. Chmielnicki, A. Dybała, M. Stachura, Activity Rules of Economic Man in Society as the Source of Legal Norms, Warszawa 2010, p. 174-185; the research method and the theoretical assumptions underlying the research presented herein, were developed by P. Chmielnicki who was also the team leader of the research project. 
of the factors which determined the formalization of specific types of activity. The diagram shows that the number of adopted laws continued to grow quite rapidly during the first ten years following the collapse of communism, until 2001 (an increase from about 50-100 bills passed per year in the early 1990s, up to 250-300 acts in the early 2000s).This growth trend slowed down in the following years, and the number of adopted acts remained at a stable level until 2012-2013 when it rapidly declined to a little over 100 bills passed in one year.

\section{Analysis of research results}

This article presents results of research into one of the research questions. The question concerns a crucial issue to the society and to the economy, namely, whether or not a given regulation facilitates the assessment of chances to achieve a desired economic goal, whether it fosters the sense of confidence in business environment and a lower risk of business failure (e.g., as a result of force majeure, or competitors' activities, or arbitrary decisions by political authorities). A positive value was accordingly assigned when a new regulation enabled a more precise calculation of the opportunities and threats, or a more accurate projection (especially in relation to regulations concerning information made available to entrepreneurs, more accurate assessment of various formal requirements applicable to business activities, and enabling entrepreneurs to better monitor the activities of the public authorities and business competitors). Access to additional financial resources need not be related to these matters, and it justifies the assignment of a positive

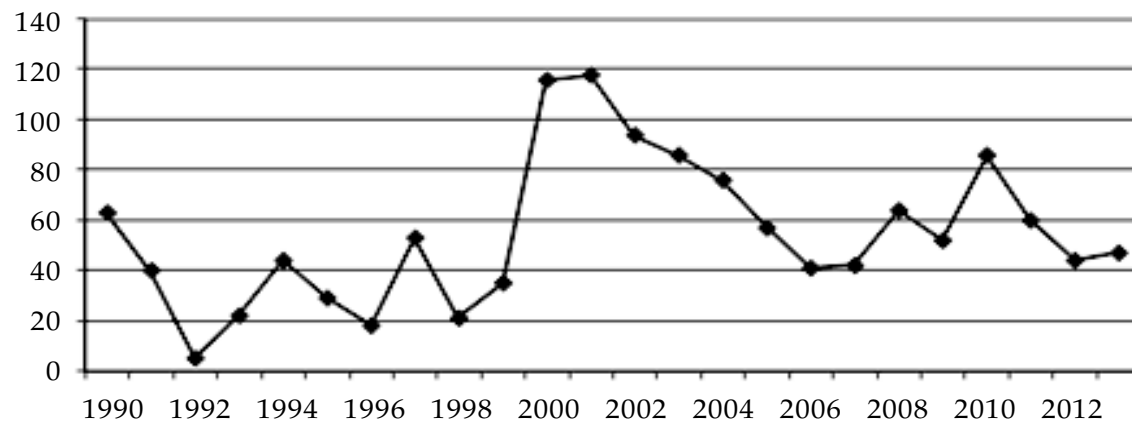

Fig. 2: Diagram based on aggregate figures for the years 1990-2013.

Source: P. Chmielnicki, E. Inglot-Brzęk and I. Styn. 
value to a regulation only in certain specific cases, for example, involving financial guarantees provided for transactions by the government.

One of the most important challenges faced by law makers concerns ensuring the safety of business operations. In the old days, taking risks was a common thing to do for homo economicus. Before setting out on a voyage with merchandise, a merchant would clear his conscience and execute his last will because there was always the possibility that the commercial voyage might separate him from his closest relatives for ever. Nowadays, entrepreneurs rather make provisions for "calculated risks" which at worst may result in obtaining lower returns. They expect the state to create an environment in which business risks would be minimised to the greatest possible extent. Therefore, the key issue to the safety of business transactions today is an undisturbed functioning of the banking services sector.

Commercial banking services which grew very quickly in Poland in the 1990s required the establishment of a system to secure the sector against destabilisation of the market for its services.

The incredibly rapid growth of the commercial banking network in Poland may be evidenced by the following figures: at the end of 1990, there were 53 nationwide banks, and in 30 of them the majority of shares were in private hands One year later there were 66 nationwide banks, including ten with foreign shareholding. In mid-1992 there were as many as 83 nationwide banks (including 15 state-owned banks), and only in eight of them the share capital was predominantly owned by foreign investors.

The Act on the Bank Guarantee Fund of $2^{\text {nd }}$ December $1994^{3}$ provided guarantees to bank account holders that funds deposited in their accounts would be paid in part in the event of the bank being liquidated. The law also determined the structure and the scope of activities of the Bank Guarantee Fund; it provided for the Fund's activities to be financed from contributions paid by banks, and determined the level of obligatory annual contributions to be paid to the Fund by commercial banks.

The Act on Financial Market Supervision of $21^{\text {st }}$ July $2006^{4}$ concerned a major change in the system of supervision of the financial market, which involved the establishment of a new competent authority, the Polish Financial Supervision Authority, which replaced several authorities

\footnotetext{
${ }^{3}$ J.L. 1995 No. 4, item 18.

${ }^{4}$ J.L. 2006 No. 157, item 1119.
} 
previously supervising the insurance and pension fund markets, as well as the capital and banking markets.

Other legislative authorities facilitated a reduction of the risk related to establishing business relations between entrepreneurs. The purpose of the Amendment to the Civil Code and Certain Other Acts, passed on $14^{\text {th }}$ February $2003^{5}$, was to introduce a regulation which would make it possible to prevent notorious practices related to business transactions, and in particular, non-performance of payments by contractors for services provided by subcontractors - small and medium-sized companies. On the other hand, the Act on the Provision of Business Information of $14^{\text {th }}$ February $2003^{6}$ was intended to decrease entrepreneur's risk in relation to consumers. The Act stipulated legal protection of information pertaining to the performance of obligations by consumers (information was to be disclosed solely in the event of documented direct intention to enter into a consumer loan agreement).

Among the legal regulations which reduced the risks involved in international trade transactions, one should mention, e.g., the Act on Insurance of Export Contracts Guaranteed by the State Treasury, of $7^{\text {th }}$ July $1994^{7}$. The Act provided for the insurance of contracts guaranteed by the State Treasury, in relation to transports to high default risk countries, and especially for the contracts to be insured against non-commercial risks, such as political risks or natural disasters. It also provided for the establishment of mechanisms for the state to support the promotion of Polish exports.

A whole series of regulations were dedicated to the establishment of specialised instruments for reducing entrepreneurial risks. For example, the Act on the Protection of Certain Services Provided by Electronic Means, Based on or Consisting in Conditional Access ${ }^{8}$. The act was meant to provide protection for the providers of services referred to in its title against being deprived of proceeds due to them by those who place on the market or use in business transactions prohibited equipment or other technical solutions intended to breach security features. A similar purpose was served by the Act on the Registration and Protection of the Names and Designations of Agricultural Products and Foodstuffs, and on Traditional Products, adopted on $17^{\text {th }}$ December $2004^{9}$.

\footnotetext{
${ }^{5}$ J.L. 2003 No. 50, item 408 .

${ }^{6}$ J.L. 2003 No. 50, item 424

7 J.L. 1994 No. 86, item 398.

${ }^{8}$ J.L. 2002 No. 126, item 1068.

9 J.L. 2005 No. 10, item 68.
} 
Special circumstances led to the adoption of the Act on State Treasury Guarantees for Airlines adopted on $14^{\text {th }}$ November $2001^{10}$. The purpose of the act was to calm down public anxiety following the 9/11 terrorist attacks. The guarantees provided by the State Treasury to airlines covered airlines' third-party liability arising from the use of airplanes in the event of war or acts of terror.

In sociology of economics or economics sociology textbooks, one may find assumptions close to those made in economics. Therefore, one may read there that "the role of each government with regard to the economy is to create stable and predictable macroeconomic, political, and legal conditions for the companies which, thanks to the foregoing, may develop long-term strategies and increase productivity, but not all the governments are able to provide such conditions even if they are fully aware of the need to do so"11.

In sociological terms, a description of the risk issue may refer to the concept of U. Beck's second modernity, A. Giddens's escaping universe, or P. Sztompka's late modernity. Irrespective of the term used, one should assume that the characteristics of today's world include:

(1) new types of risk (generated by civilisation and advanced technologies) which permeates all areas of life and becomes ubiquitous;

(2) new types of trust, being trust in abstract systems;

(3) non-transparency, fluidity, and uncertainty of social situations in which individuals must function, resulting in reflexivity and extreme relativism ${ }^{12}$.

Risk is unavoidable in the contemporary world, just as one may read in the following statement, "All human activities are oriented towards the future; and the future is uncertain in many respects, and therefore it involves risks. This uncertainty results to a large extent from conditional behaviour of other actors: individuals, groups, or organisations. One may never be entirely sure how partners in our interactions and social relations are going to react to one's behaviour. At the same time, any success or failure of our actions is clearly based on their reactions"13.

10 J.L. 2001, No. 137, item 1531.

${ }_{11}$ J. Gardawski et al., Socjologia gospodarki, Warszawa 2008, p. 65.

12 P. Sztompka, Socjologia. Analiza społeczeństwa, Kraków 2002, p. 575-578.

${ }^{13}$ P. Sztompka, Zaufanie, nieufność i dwa paradoksy demokracji, in: Socjologia. Lektury, ed. by P. Sztompki, M. Kucia, Kraków 2005, p. 397. 
Risk at individual and group levels may be traced back to the concept of culture types ${ }^{14}$. The culture influences attitudes, values and opinions, which also includes people's willingness to individually carry the risk involved in their own actions, the value seen in work, or the willingness to save, invest, compete, etc. The culture may be a conservative factor (anti-development culture) or an innovative factor (pro-development culture $)^{15}$. Anti-development cultures are mainly linked with traditional societies (lasting, reproductive, risk-free), and pro-development cultures with modern societies. The modernization as a social process which accompanied the transition from a traditional to a modern society "de-tabooised" the world and made it the target of practical activities. Individuals became conscious of creating their own lives, and the market and competition, albeit creating a significant risk, have become preconditions for personal success.

When analysing the situation in Poland one should stress that, under communism, social modernisation was quite limited, and the society functioned in conditions close to those of a traditional society. Restrictions with regard to ownership rights and opportunities for an individual to achieve wealth, a crippled market, a critical opinions about the "innovators" who wanted to create their own lives, have led to a situation that only during the period of structural reforms conditions were established for the development of a modern society. However, modernisation was accompanied by the emergence of risk and the need to reduce it, which is reflected in the number of adopted regulations. Nevertheless, it should be noted that laws may be changed relatively quickly, but a change in culture patterns requires a much longer time to occur.

The main problem results from the fact that the scope of risk is expanding and successively affects new areas of individual and group life. According to Beck, when the Western civilisation entered the phase of the "second modernity", it has been transforming today's societies into the so called risk society. The continuous emergence of new forms of risk forces individuals to react and adjust to these forms of risk. Therefore, all decisions involve risk, meaning an event which motivates our actions, although this event has not even happened yet ${ }^{16}$. Thus, risk is

${ }^{14}$ E. Cierniak-Szóstak, Gospodarka w perspektywie socjologicznej, in: Odkrywanie socjologii. Podręcznik dla ekonomistów, ed. by A. Karwińska, Warszawa 2007, p. 222-224.

${ }^{15}$ W. Morawski, Socjologia ekonomiczna, Warszawa 2011.

${ }^{16}$ U. Beck, Społeczeństwo ryzyka. W drodze do innej nowoczesności, Warszawa 2002, p. 44. 
unavoidable and is oriented towards change. As D. Markowski noted, "If the term risk comprises some possible calculation related to an assessment of anticipated results which will be achieved as a consequence of actions to be undertaken, irrespective of whether the risk is taken by an individual or it results from interpersonal relationships at different levels within social structures, the assumed outcome of risk is some desirable change" 17 .

A growing risk related to actions taken by an individual is well illustrated by Sztompka's observation that "this risk keeps growing as our potential partners become more numerous, more diversified, more distant in space, less visible; to put it shortly, when our social environment expands, becomes more complicated, less transparent and less controllable"18.

Thus risk presents itself as an immanent feature of today's world and exists both at individual and group levels. Among the socially desirable forms of risk control, especially with regard to the functioning of the market and the economy, one should mention regulations introduced by national authorities. However, as noted by Beck, the entire responsibility for controlling risk must not be left up to politicians. Their efforts must be joined by other groups which operate in the "sub-political" sphere. These include all the movements and groups which may exert significant influence on politics ${ }^{19}$.

Sociologists view the so called network relations between participants (both at individuals and groups) of market games as forms of risk control. The network as a type of bond constitutes a system of lasting, meaningful relations of both formalised and not formalised nature ${ }^{20}$. When actors join in for the purpose of pursuing joint economic interests this is referred to as a consolidated network ${ }^{21}$.

Network relations provide the basis for the development of an important market resource, which is referred to as the social capital. At the macro level of society as a whole, it is the factor regulating market relations and the resource according to which the actors' market positions

${ }^{17}$ D. Markowski, Ryzyko zmiany. Struktury w kształtującym się społeczeństwie obywatelskim, Rzeszów 2009, p. 21.

${ }^{18}$ P. Sztompka, Socjologia..., p. 310.

${ }^{19}$ A. Giddens, Socjologia, Warszawa 2006, p. 697.

${ }^{20}$ L. Gilejko, Instytucje ekonomiczne, in: Socjologia ogólna, wybrane problemy, ed. by J. Polakowska-Kujawa, Warszawa 2004, p. 331.

${ }^{21}$ J. Gardawski et al., op. cit., p. 87. 
are differentiated. This capital, also referred to as network capital, may exist at individual, group, or institutional level. Trust and reciprocity are the most important values to each of these dimensions. It is possible to measure the value of social capital and trust. According to R. Putnam, they contribute to reducing uncertainty in social life, thereby reducing transaction costs ${ }^{22}$. M. Federowicz noted that, "Networks of actors have substantial influence on the ways in which individual actors try to reduce the scope of uncertainty inevitably involved in making important decisions" ${ }^{\prime 23}$.

Apart from social capital based on trust, market risk is also regulated by institutional factors. Institutions are an important factor of change and constitute an important component of change and development, as well as a stabilising and balancing factor. Fedorowicz observed that, "Institutions suggest certain activity patterns to participants of the game, and help them to achieve the optimum and stable result" ${ }^{\prime 24}$. Nonetheless, social capital plays an important role in institutional regulations as well. Francis Fukuyama stated that modern societies have established various institutional and legal frameworks for the economy to operate (by agreements, codes). They enable business relationships to be kept by parties which are strangers to each other, but the same process is much more efficient when the parties trust each other"25.

The above discussion shows that the terms "risk" and "trust" are interrelated. Therefore, one may agree with Giddens that today societies live in a world in which trust should be placed alongside new types of risk and uncertainty.

Trust should accompany each relationship between actors participating in market games. In the conditions of uncertainty trust becomes a kind of a "wager" that individuals or institutions will behave in a specific manner, and so their actions will not be entirely unpredictable. However, trust is not "blind". One does not trust an individual or an institution based on what they are saying. One believes them because one knows their nature and abilities; one knows what choices they have, and what the consequences of these choices are, and so on. Under these

${ }^{22}$ R. Putnam, Społeczny kapitat a sukces instytucji, in: Socjologia. Lektury, op. cit., p. 388-389.

${ }^{23}$ M. Federowicz, Różnorodność kapitalizmu. Instytucjonalizm i doświadczenie zmiany ustrojowej po komunizmie, Warszawa 2004, p. 100.

${ }^{24}$ Ibidem, p. 67.

${ }^{25}$ F. Fukuyama, Zaufanie. Kapitat społeczny a droga do dobrobytu, Warszawa 1997, p. 117. 
circumstances one expects them to choose to do what they promised ${ }^{26}$. Trust is based on calculations taking into account an assessment of reliability (reputation, prior record, physical attributes and symbols), as well as an assessment of the level of trust which may be offered in a given situation ${ }^{27}$. Not only reliability, but also the structural context and the situation are important, and specifically, the existence of agencies which force acting in a trustworthy manner and reducing the chances for arbitrariness and breach of trust.

Sztompka does not treat one's willingness to trust as a characteristic of an individual, but as an orientation typical of a greater group. This may be seen especially when trust is vested in abstract systems (companies, institutions, organisations, markets, etc.). Therefore Sztompka observes the existence of a culture of trust (trust as a cultural orientation commonly found in a given society). This culture may take various forms depending on the strength of positive expectations. One may expect instrumental efficiency (regularity, correctness, predictability, competence, efficiency), high moral standards (e.g., that the government will ensure justice, fairness, and equal opportunities), or trusted care (representation of interests, assistance, security). The greater the expectations, the greater the risk and possibility for disappointment. The culture of trust is contrasted with the culture of cynicism which increases transaction costs (each of the parties must be alert and maintain control at all times), limits cooperation, and reduces the possibility for enforcement of laws ${ }^{28}$.

A comparison of numerous surveys (by the World Bank, the European Social Survey, the Social Diagnosis, and CBOS) shows that the Polish society continues to be characterised by a low level of trust and social capital. Poles show high levels of trust only towards those closest to them. They do not show any of so called general trust (in other people), or trust in business relationships, or trust in their law makers and the government ${ }^{29}$. According to Sztompka, both trust and distrust are functional, provided that they are confirmed epistemologically. On the other hand, both unjustified trust and unjustified distrust are dysfunctional.

${ }^{26}$ P. Desgupta, Trust as a Commodity, in: Trust: Making and Breaking Cooperative Relations, ed. by D. Gambetta, Oxford 1988, p. 50-51.

${ }^{27}$ P. Sztompka, Socjologia..., p. 313.

${ }^{28}$ Ibidem, p. 310-311.

${ }^{29}$ R. Boguszewski, Zaufanie w relacjach międzyludzkich, CBOS, BS 29/2014: A. Cybulska, K. Pankowski, Stosunek do instytucji państwa oraz partii politycznych po 25 latach, CBOS, NR 68/2014; Raport Polska 2030. Wyzwania rozwojowe. 
Ways to overcome the unjustified distrust shown by Poles should be sought in the description of seven conditions (structural contexts) which either promote trust or reinforce distrust. These include:

- Normative certainty or normative chaos or anomie;

- Transparency of social organisations or their secrecy and lack of transparency;

- Stability of the social order or its fluidity and fragility;

- Responsibility of the authorities or their arbitrariness and lack of responsibility;

- Enforcement of laws and assignment of obligations or helplessness towards breaches of law;

- Enforcement of obligations and fulfilment of commitments or permissiveness;

- Ensuring the dignity, integrity and autonomy of each member of the society or instrumental treatment ${ }^{30}$.

Sztompka links opportunities for the emergence of a culture of trust with the paradox of democracy, namely, the institutionalisation of distrust (the mechanism provides safeguards against those who would like to expose trust to risk; discourages the breach of shortfalls in trust; and corrects breaches of trust). As a result, he notes that "the greater the extent of institutional distrust, the more spontaneous the trust becomes $^{\prime \prime 31}$. Departing from model assumptions, he agrees that, in order for a culture of trust to be developed in a social reality, it is vital that:

- democracy should be reliable (consistently, invariably, and universally);

- the checks and balances procedures in place should be "sparse", as the last resort and safeguard measure. Therefore, alternative loops of self-reinforcing causality should be initiated: (1) negative, consisting in increased inspection and control in the event of lack or breach of trust; and (2) positive, meaning less control and inspection where reactions are based on trust ${ }^{32}$.

In order to reinforce trust it is necessary to make people and/or institutions responsible, and increase the costs of breaching trust.

The final third element related to a description of risk is nontransparency, fluidity and uncertainty of social situations in which individuals are required to act nowadays, which leads to reflexivity and extreme

\footnotetext{
${ }^{30}$ P. Sztompka, Socjologia..., p. 318-319; idem, Zaufanie..., p. 400-403.

${ }^{31}$ P. Sztompka, Zaufanie..., p. 403.

32 P. Sztompka, Socjologia..., p. 322.
} 
relativism. The concept of reflexivity was introduced by A. Giddens who observed that in today's world nations are challenged not so much by enemies, be it external or internal, but rather a growing level of risk. Traditional forms of trust are being exhausted now, and they are being replaced with faith in "abstract systems" (e.g., confidence in the functioning of banking systems). Therefore, life makes it necessary for individuals to be reflexive, meaning that they must continuously analyse their life circumstances and make their choices. The only ones able to control the escaping world of today are state governments which join forces in actions undertaken, on the one hand, together with other governments, and on the other, with institutions and movements functioning outside the formal structures of political life ${ }^{33}$.

E. Wnuk-Lipiński also referred to an increase in reflexive attitudes in today's world, and he associated the growing risk with a greater freedom. According to him, "the ability to transgress structural and cultural circumstances induces the actors' responsibility for the consequences of their actions on the one hand, and on the other introduces an element of isk into social relationships. [...] Free market and democracy organise the life of a society in such way that they increase the importance of agents in shaping the course of social relations and, at the same time, increase the area of uncertainty and risk" ${ }^{\prime \prime}$.

In sociology, the issue of reducing risk is not limited to the number of adopted regulations and the possibility of translating these regulations into a more detailed calculation of the opportunities and threats involved in actions which are being undertaken. It is an important element because it shows the existing institutional set-up, but in a way, it is of a secondary significance. The broad context in which individuals, groups and institutions function today is more important. This context is defined by such terms as: agency, relational networks, trust, social capital, and culture of trust.

\section{Conclusions}

The research question discussed in this chapter concerned regulations which determine a higher likelihood of results of anticipated business ventures and enable making more accurate projections. These may be

\footnotetext{
${ }^{33}$ A. Giddens, op. cit., p. 698-699.

${ }^{34}$ E. Wnuk-Lipiński, Socjologia życia publicznego, Warszawa 2008, p. 98.
} 
both regulations which increase the level of certainty that a result will be achieved, as well as a greater certainty that a particular project will fail under specific circumstances. Both types of information are equally vital to making decisions on economic matters.

People rarely operate under perfect conditions assumed in the rationale of the economic man: with full access to information, and a sufficient time to make the decision. The effectiveness of the decision making process does not depend on access to information in general, meaning any information. The information should not only be accurate, which is obvious, but it should also be relevant to the decision making process, meaning that it should be substantially important from the point of view of the decision to be made. As a rule, the circumstances do not afford full access to relevant information, and premises may not even be available in order to determine which information is relevant, and what information is required. Too little information makes it difficult to make a decision, but too much information also constitutes a threat because it becomes necessary to separate relevant and irrelevant information, which is not an easy task in today's world. And people very often are not even able to determine what information they need in order to make a decision.

Therefore the choice of a ready activity pattern provided by the society is a rational one because it suggests that it might be possible to avoid making a mistake under the pressure of circumstances (abundant information, insufficient time, inability to process information effectively). Solutions approved by the society, including legal regulations, are treated (and usually rightly so) as tested, based on full relevant information, and rationally designed. Although the development of legal mechanisms also takes place under the same circumstances as other human activities, that is, in the absence of full information and under time pressure, but activity patterns encouraged by the society benefit from a certain presumption of good quality (as being more effective and rational) by the mere fact of having originated from the group, as compared to the strategies developed by individuals. As a rule people are aware of the importance of the pressure of circumstances, the threats involved, and they are even more interested in finding ready mechanisms which they might use in order to avoid the consequences of making a mistake.

Reducing entrepreneurial risk (through direct regulation) has been a gradually growing trend in legislative initiatives. Based on the analysis 


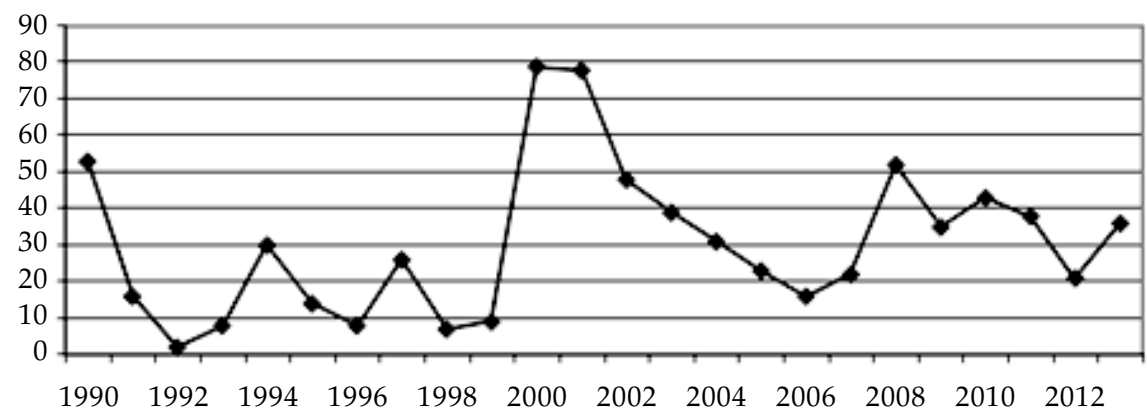

Fig. 3: Diagram based on aggregate figures with a "cut off at 2" for the years 1990-2013. Source: P. Chmielnicki, E. Inglot-Brzęk and I. Styn.

of research findings, a slight long-term growth tendency may be observed in the legal regulations concerning the reduction of risks involved in economic decisions made by entrepreneurs (with regard to the regulations directly concerning the matter).

One may notice (see Fig. 3 which covers only the regulations which were assigned values 2 or 3 , that is concerning the most important legislative initiatives) that Polish law makers, in the long term, have been placing a significant and growing stress on creating conditions to decrease the risk involved in business operations, employing stimuli facilitating the optimisation of decisions made by entrepreneurs as well, so that the decisions can be made in line with the theory of rational choice.

\section{REDUKCJA RYZYKA PRZEDSIĘBIORCY JAKO PRZEDMIOT INICJATYW LEGISLACYJNYCH. WNIOSKI Z BADAŃ}

\section{Streszczenie}

Artykuł dotyczy problemu długookresowych tendencji zachodzących w procesie stanowienia prawa w Polsce. Teoretycznym uzasadnieniem występowania takich tendencji jest założenie, że człowiek zwykle działa zgodnie z gotowymi schematami, zaakceptowanymi przez zbiorowość, które obejmują normy (reguły) należące do trzech podstawowych kategorii: (1) reguły dotyczące zdobywania dóbr za pomoca wymiany towarowo-pieniężnej, (2) reguły odnoszące się do pozyskiwania dóbr poprzez powołanie się na uprawnienia wynikające z przynależności do zbiorowości oraz (3) normy prawne, których rolą jest ochrona i upowszechnienie reguł należących do dwóch pierwszych kategorii. W rezultacie popyt na sposoby zaspokajania potrzeb determinowany określonymi regułami zwiększa podaż norm prawnych związanych z określonym zagadnieniem społeczno-gospodarczym. Skutkuje to pojawianiem się tendencji długookresowych w tworzeniu źródeł prawa, które 
można badać metodami empirycznymi, przedstawionymi w niniejszym artykule. W opracowaniu prezentowane są wyniki analiz dotyczących jednego z pytań badawczych, odnoszącego się do ważnego problemu społeczeństwa i gospodarki, jakim jest kwestia, czy regulacja ułatwia ocenę szans na osiągnięcie zakładanego celu gospodarczego, czy służy wzmacnianiu poczucia pewności obrotu gospodarczego, zmniejszeniu ryzyka niepowodzenia w działalności gospodarczej. We wnioskach zawarta jest teza, że zmniejszanie ryzyka przedsiębiorcy (przez regulacje bezpośrednie) jako trend w prawodawstwie systematycznie się umacnia. Analiza danych $\mathrm{z}$ badań pozwala zauważyć delikatny długoterminowy trend wzrostowy w ustawodawstwie, jeśli chodzi o zmniejszanie ryzyka gospodarowania przez przedsiębiorcę (w postaci regulacji bezpośrednio dotyczących tej tematyki). Można zauważyć, iż polski ustawodawca - w ujęciu długookresowym - kładzie duży, rosnący nacisk na tworzenie warunków do zmniejszania ryzyka obrotu gospodarczego.

Słowa kluczowe: ekonomia instytucjonalna - źródła prawa - proces stanowienia prawa - teoria i filozofia prawa 